\title{
Homeostatic Model Assessment of Insulin Resistance
}

National Cancer Institute

\section{Source}

National Cancer Institute. Homeostatic Model Assessment of Insulin Resistance. NCI

Thesaurus. Code C100447.

An assessment of beta-cell function and insulin resistance based on fasting blood glucose and insulin concentrations. 